\title{
Carcinoma cutáneo de células de Merkel. Presentación de un caso y revisión de la literatura
}

\section{Cutaneous Merkel cell carcinoma. Case report and literature review}

\author{
J.M. López-Arcas ${ }^{1}$, J.L. Cebrián Carretero², E. Palacios', J. Macarrón³, L. Pingarrón', G. Demaría', \\ M. Burgueño ${ }^{4}$
}

Resumen: El carcinoma de células de Merkel, constituye una variedad infrecuente de cáncer cutáneo, de origen neuroendocrino, que clásicamente se describe, como la malignidad cutánea de peor pronóstico. Se origina a partir de las células de Merkel o receptores cutáneos de presión. Presenta un patrón infiltrativo dermo-linfático así como extensión linfática nodal y diseminación hematógena. Presenta numerosas similitudes con el carcinoma pulmonar de células pequeñas, con una sensibilidad intrínseca a la quimio-radioterapia y un gran potencial metastático. Los mejores resultados se obtienen cuando se combina un diagnóstico precoz y el tratamiento combinado con cirugía- radio y quimioterapia. La principal dificultad que presentan estos tumores es la avanzada edad de la población en que se presentan y la localización de los mismos, que en ocasiones limitan las opciones terapéuticas disponibles. Presentamos un caso de carcinoma de células de Merkel facial, tratado con cirugía y radioterapia. Se realiza una revisión de la literatura.

Palabras clave: Células Merkel; Cáncer de piel.

Recibido: 31.01 .07

Aceptado: 17.09 .07

\begin{abstract}
Merkel-cell carcinoma is a rare skin cancer of neuroendocrine origin, which has been described as the most aggressive skin malignancy. The tumor arises from the Merkel cells, or skin pressure receptors. It has an infiltrative growth pattern and spreads by the lymphatic vessels and blood. It is similar to small cell lung carcinoma, with an intrinsic sensitivity to chemo-radiotherapy and a remarkable tendency to metastasize. The best treatment outcomes are obtained with early diagnosis and a combination of surgery, chemotherapy, and radiotherapy. A clinical case of Merkel cell carcinoma of the face treated with surgery and radiotherapy is reported and the literature is reviewed.
\end{abstract}

Key words: Merkel cells; Merkel cancer; Skin cancer.

\section{Correspondencia:}

Dr. José María López-Arcas Calleja

Servicio de Cirugía Oral y Maxilofacial. Hospital Universitario La Paz.

Paseo de la Castellana 286

28046 Madrid, España

Email: drlopezarcas@tiscali.es 


\section{Introducción}

El carcinoma de células de Merkel, constituye una variedad infrecuente de cáncer cutáneo, de origen neuroendocrino, que clásicamente se describe, como la malignidad cutánea de peor pronóstico. Se origina a partir de las células de Merkel o receptores cutáneos de presión. Estas células fueron descritas por primera vez en 1875 y se les atribuye la función de mecanorreceptores de acción lenta situados en la capa basal de la epidermis.

Fue descrito por primera vez en 1975 por Toker, ${ }^{1}$ que lo definió como carcinoma de células "trabeculares". Con estudios de inmunofluorescencia y microscopía electrónica posteriormente en 1978, se pudo identificar la célula de origen de esta patología. ${ }^{2}$ Afortunadamente constituye una variedad infrecuente de carcinoma cutáneo. Apenas se han recogido unos 2.000 casos desde su descripción inicial. Se presenta en individuos mayores, con una media de edad al diagnóstico de unos 69 años, ${ }^{3}$ siendo $2-3$ veces más frecuente en varones.

En cuanto a sus factores etiológicos, destaca por encima de todos la exposición solar, como lo demuestra el hecho de que la mayor parte de las lesiones aparezcan en zonas expuestas, especialmente en la región periorbitaria. Otros factores asociados incluyen: inmunodeficiencias, exposición a arsénico, displasia ectodérmica y enfermedad de Hodgkin. ${ }^{4}$

Clínicamente suele presentarse como un nódulo eritemato-violáceo, que presenta una superficie brillante y característicamente una telangiectasia brillante. Es frecuente la confusión con otro tipo de patologías como el carcinoma basocelular, melanomas amelanóticos o incluso con los linfomas cutáneos.

Tiene un patrón de diseminación linfática, favoreciendo la aparición de numerosas lesiones satélites. La afectación ganglionar está presente en $1 / 3$ de los casos. La diseminación hematógena, ocurre en el $50 \%$ de los casos a lo largo del curso de la enfermedad.

Se ha documentado la regresión de la lesión principal. En un 10$20 \%$ de los casos no se evidencia tumor primario, lo que en este caso constituye un signo de buen pronóstico. ${ }^{5}$

Generalmente se localiza en la dermis y puede extenderse a epidermis o al tejido subcutáneo. Las características citológicas típicas incluyen la triada: núcleo vesicular con nucleolos de pequeño tamaño, abundantes mitosis y apoptosis. Se han descrito tres variantes histológicas (intermedia, células pequeñas y trabeculado) que no parecen tener relevancia clínica. ${ }^{6}$

No existe un sistema específico de estadiaje para el Carcinoma de células de Merkel, 7 pero generalmente se clasifican en:

- Estadio IA: enfermedad local $<2 \mathrm{~cm}$

- Estadio IB: enfermedad local $>2 \mathrm{~cm}$

- Estadio II: afectación ganglios linfáticos

- Estadio III: Enfermedad metastásica.

El tratamiento va a depender del estadio de la enfermedad. El tratamiento más uniformemente aceptado es la extirpación quirúrgica de la lesión primaria con márgenes de unos $2,5 \mathrm{~cm}+$ radioterapia postoperatoria de la localización primaria y de las cadenas linfáticas locorregionales.

\section{Introduction}

Merkel cell carcinoma is an infrequent variety of skin cancers of neuroendocrine origin, which traditionally is described as the skin malignancy with the worst prognosis. It originates from Merkel cells, or cutaneous pressure receptors. These cells were described for the first time in 1875. They are located in the epidermal basement layer and are said to be slow action mechanoreceptors.

Merkel cell carcinoma was first described in 1975 by Toker, ${ }^{1}$ who defined it as a trabecular cell carcinoma. Immunofluorescence studies and electronic microscopy allowed the cell of origin of this pathology to be identified in 1978. ${ }^{2}$ It is, fortunately, an uncommon variety of skin cancer. Barely 2,000 cases have been reported since the initial description. It occurs in older people, the mean age of diagnosis being about 69 years; it is 2-3 times more frequent in men.

The etiological factors include, above all, sun exposure, as demonstrated by the fact that most lesions occur in exposed areas, especially the periorbital region. Other associated factors include: immunodeficiency, arsenic exposure, ectodermal dysplasia, and Hodgkin's disease. ${ }^{4}$

Clinically it usually presents as an erythematous-purplish nodule with a shiny surface and, typically, telangiectasia. Confusion with other pathologies, like basocellular carcinoma, amelanotic melanoma or cutaneous lymphomas, is common.

It has a pattern of lymphatic dissemination that favors the appearance of numerous satellite lesions. Lymph node involvement is present in one-third of cases. Hematogenous dissemination occurs in $50 \%$ of cases in the course of the disease.

Regression of the main lesion has been documented. In 10-20\% of cases, the primary tumor is not demonstrated, which is a sign of good prognosis in this case. ${ }^{5}$

It is generally located in the dermis and can extend to the epidermis or subcutaneous tissue. The typical cytological features include the triad: vesicular nucleus with small nucleoli, abundant mitoses, and apoptosis. Three histological variants have been described (intermediate, small cell, and trabecular), but they do not seem to have clinical relevance. $^{6}$

No specific staging system for Merkel cell carcinoma exists, ${ }^{7}$ but the tumor is generally classified as:

- Stage IA: local disease $<2 \mathrm{~cm}$.

- Stage IB: local disease $>2 \mathrm{~cm}$.

- Stage II: lymph node involvement.

- Stage III: metastatic disease.

Treatment depends on the disease stage. The treatment most generally accepted is surgical excision of the primary lesion with margins of about $2.5 \mathrm{~cm}$ and postoperative irradiation of the primary location and local and regional lymph node chains. 


\section{Descripción del caso}

Mujer de 72 años de edad que acude a nuestra consulta por presentar una lesión cutánea nodular, eritematosa, de superficie brillante (Figs. 1 y 2), de crecimiento rápido, en mejilla derecha, de 5 meses de evolución que no ha mejorado con tratamiento tópico con corticoides de baja potencia pautado progresivamente por su médico de cabecera. Se realizó biopsia de la lesión que arrojó el diagnóstico de Tumor de Merkel (Fig. 3).

No se palpaban adenopatías cervicales. Analítica preoperatoria, incluyendo marcadores tumorales, normal salvo el valor de la glucemia de 177. TC cervical sin hallazgos de afectación ganglionar cervical donde únicamente se aprecia la existencia de una lesión cuánea en la región malar derecha que coincide con la localización externa de la lesión. No se aprecia afectación ósea (Fig. 4). Rastreo corporal con TC toraco-abdominal igualmente sin hallazgos susceptibles de invasión sistémica.

Bajo Anestesia General se procedió a la extirpación de la lesión con márgenes oncológicos y reconstrucción con colgajo cutáneo de rotación-deslizamiento cérvicofacial (Figs. 5-7). Posteriormente se administró Radioterapia externa con una dosis total acumulada de 60 Gy. 12 meses después de la intervención quirúrgica la paciente presentó en una revisión programada, una tumoración submandibular cuya PAAF fue informada como metástasis cervical de Carcinoma cutáneo de células de Merkel. Se realizó Disección cervical Radical, cuyo resultado fue de 2 ganglios afectos, ninguno de ellos presentando afectación extracapsular (Fig. 8).

\section{Discusión}

La mayor parte de los pacientes presentan una enfermedad localizada al diagnóstico, $70-80 \%$ en estadio I. Entre un 10-30\% presentan afectación ganglionar (Estadio II), y menos de un 5\% enfermedad metastásica. En nuestro caso, inicialmente la paciente fue clasificada en el estadio I. Dado el corto periodo de evolución entre la fecha de la intervención y el tratamiento

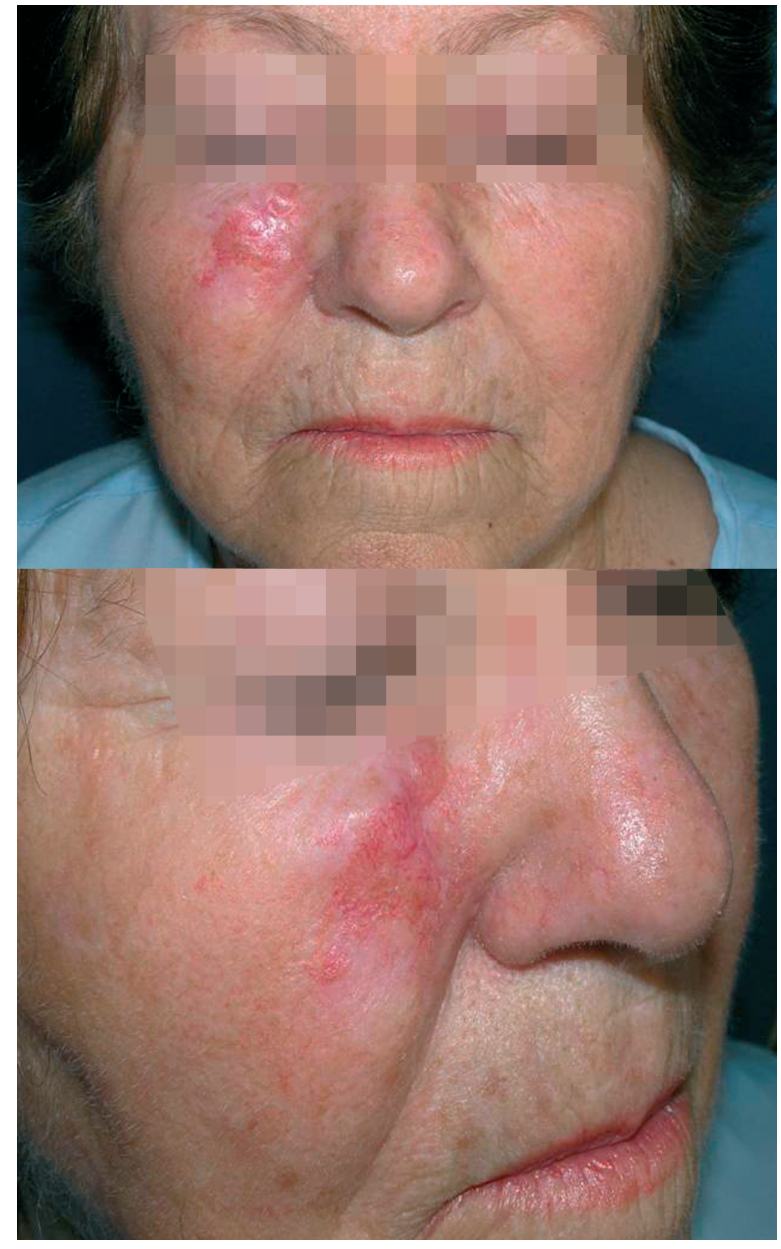

Figuras 1 y 2 . Aspecto de la lesión al diagnóstico. Se trata de una lesión nodular, eritemato-violácea de superficie brillante con telangiectasias asociadas.

Figures 1 and 2. Appearance of lesion at time of diagnosis. The nodular lesion is erythematous-purplish with a shiny surface and associated telangiectasias.

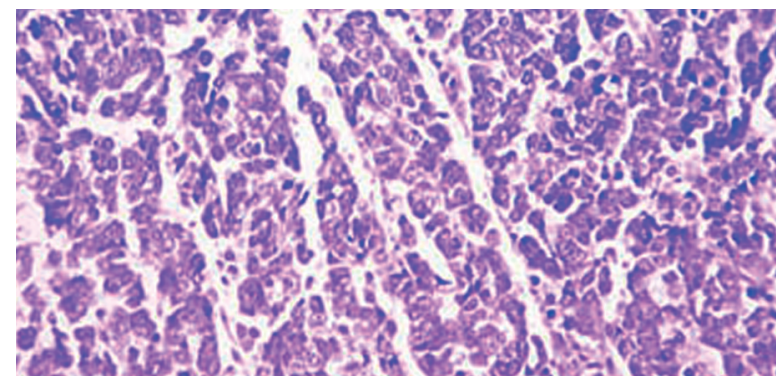

Figura 3. Microfotografía de la biopsia lesional. Se aprecian células basófilas, uniformes, núcleo redondo u ovalado, cromatina dispersa, nucleolos pequeños, membranas netamente definidas y citoplasma escaso.

Figure 3. Microphotography of the biopsy of the lesion. Uniform basophilic cells with a round or oval nucleus, dispersed chromatin, small nucleoli, defined membranes, and scant cytoplasm are appreciated.

\section{Case description}

A 72 year-old woman was seen in our clinic for a rapidly growing, nodular, erythematous skin lesion with a shiny surface (Figs. 1 and 2) in the right cheek, that had appeared 5 months earlier and had not improved with topical treatment with low-strength corticoids prescribed progressively by her family physician. Biopsy of the lesion confirmed the diagnosis of Merkel's tumor (Fig. 3).

No cervical lymph nodes were palpated. The preoperative blood tests, including tumor markers, was normal except for blood glucose 177. Cervical CT did not disclose cervical lymph node involvement. A skin lesion in the right malar region, coinciding with the external location of the lesion, was the only finding. Bone involvement was not observed. A whole-body scan with thoraco-abdominal CT did not reveal systemic invasion (Fig. 4).

The lesion was excised under general anesthesia with oncological margins and the skin was reconstructed with a cervicofacial rotation-sliding skin flap (Fig. 5-7).5-7 External irradiation followed with a cumulative total dose of $60 \mathrm{~Gy}$. Twelve months after surgery, a submandibular tumor was found during a scheduled follow-up visit; the FNAB revealed cervical metastasis of cutaneous Merkel cell carcinoma. Radical cervical dissection disclosed disease in two lymph nodes, neither of which presented extracapsular involvement (Fig. 8).

\section{Discussion}

Most patients have localized disease at the time of diagnosis, $70-80 \%$ in stage I. Lymph node involvement (Stage II) is present in 10-30\% and metasta- 
radioterápico con la aparición de la metástasis cervical, probablemente se tratase inicialmente de un estadio II con afectación ganglionar microscópica.

En cuanto a la evolución clínica, el factor de peor pronóstico es la existencia de afectación ganglionar. Es por ello, que algunos autores abogan por un tratamiento quirúrgico inicial de las estructuras linfáticas cervicales, no sólo por el alto riesgo de metástasis cervicales sino también por su mal pronóstico una vez presentes. En este caso optamos por administrar Radioterapia postoperatoria dada la ausencia de clínica de afectación ganglionar. Es la opinión de los autores, que quizás una actitud adecuada en este tipo de casos debería incluir la realización de un estudio mediante Técnica de Ganglio Centinela para el estudio de micrometástasis.

Otros factores de mal pronóstico son: afectación de miembros inferiores, tamaño de la lesión $>2 \mathrm{~cm}$, edad superior a 60 años y ausencia de radioterapia en el tratamiento.

Es importante a la hora de realizar el diagnóstico, estudiar la extensión de la enfermedad Hay que investigar la existencia de lesiones satélites y de sembrado dérmico y se deben palpar las cadenas linfáticas de drenaje. Estudios complementarios incluyen: TC, PET-TC y gammagrafía con octreótido marcado. ${ }^{7}$ Hay que estudiar especialmente el Tórax e hígado para descartar tanto una diseminación metastásica como un probable origen primario a partir de un carcinoma de células pequeñas. En nuestro caso, ni previo a la primera intervención ni en el momento de la recidiva metastásica cervical se evidenció afectación sistémica.

\section{Tratamiento}

El principal objetivo del tratamiento debe ser el control locorregional tanto de la lesión primaria como de los nódulos linfáticos asociados, que permita una mayor calidad de vida y una disminución del riesgo de diseminación de la enfermedad. Como objetivos secundarios incluiríamos la preservación de la estética y la función.

En nuestro caso, dada la ausencia de afectación del esqueleto óseo se procedió a realizar una extirpación amplia con márgenes de $3 \mathrm{~cm}$ (salvo en el margen palpebral donde fueron de $2 \mathrm{~cm}$ ) incluyendo el periostio subyacente asegurandose de descartar la presencia de afectación ósea.

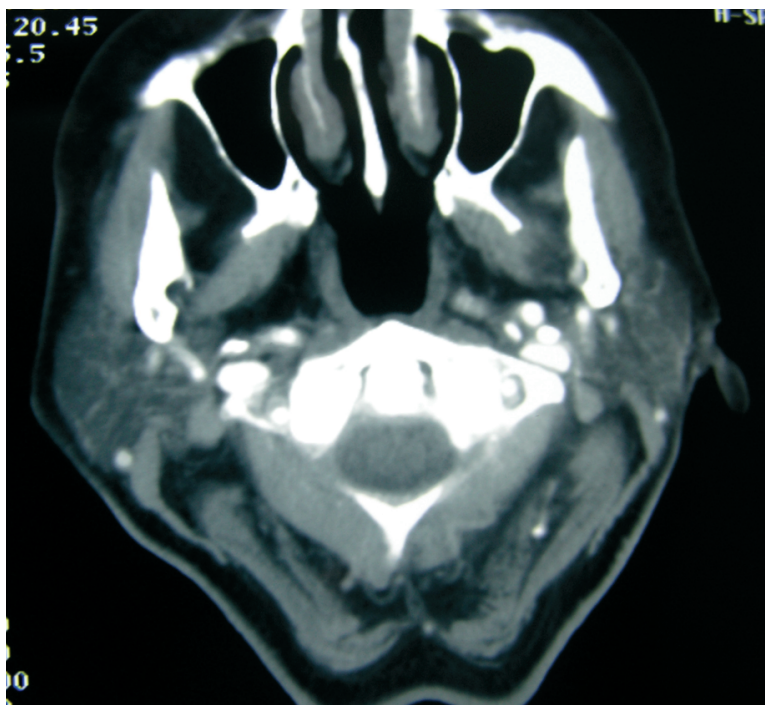

Figura 4. Imagen de TC de la lesión en la que se aprecia la tumoración nodular cutánea en la región malar derecha. the right malar region.

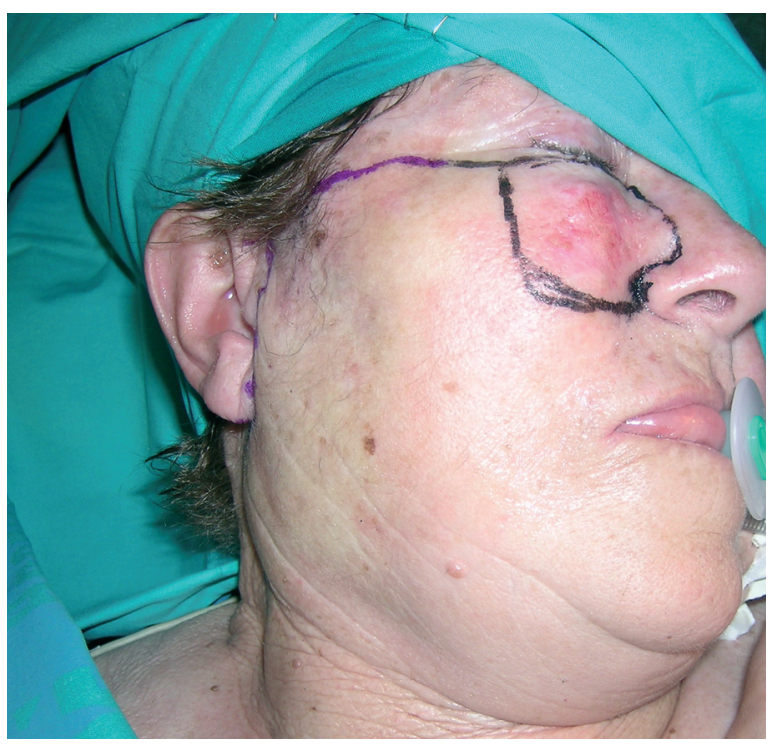

Figura 5. Imagen intraoperatoria previa a la extirpación con diseño del colgajo regional para reconstrucción del defecto. Figure 5. Intraoperative image before excision and design of a regional flap to reconstruct the defect.
Figure 4. CT image of the lesion showing a nodular skin tumor in

tic disease in less than 5\%. The case of our patient was classified initially as stage I. Given the short evolution between the date of intervention with radiation therapy and the appearance of cervical metastasis, the disease probably was initially stage II with microscopic lymph node involvement.

The most unfavorable prognostic factor with respect to the clinical evolution is the existence of lymph node involvement. For that reason, some authors recommend initial surgical treatment of cervical lymph nodes due to the risk of cervical metastasis and the poor prognosis. We chose postoperative irradiation for our patient because of the absence of clinical lymph node involvement. The authors believe that the proper approach to this type of cases should include a study by the sentinel lymph node technique to detect micrometastases. Other factors of poor prognosis are: lower limb involvement, lesion size $>2 \mathrm{~cm}$, age over 60 years, and not including irradiation in the treatment.

It is important to study the extension of the disease when the diagnosis is made. The existence of satellite lesions and cutaneous spread should be investigated and lymphatic drainage chains should be palpated. Complementary studies include: CT, PET-CT and scintigraphy with marked octreotide.7 The thorax and liver, especially, are studied to exclude metastatic dissemination and a probable primary origin from small-cell carcinoma. Systemic involvement was not demonstrated before the first intervention or at the time of cervical metastatic recurrence in our patient.

\section{Treatment}

The primary objective of treatment must be the local and regional control of the primary lesion and associated lymph 
Estadio I: Se recomienda cirugía y radioterapia. Se recomienda obtener unos márgenes de seguridad de entre 2,5 a 3 cm.6,8,9 La supervivencia media a los 5 años se estima en un $64 \%$. Numerosos autores recomiendan la utilización de radioterapia postoperatoria basados en estudios retrospectivos que comparaban pacientes tratados con cirugía únicamente frente a apacientes tratados con cirugía y radioterapia. ${ }^{10-12}$ Se aconseja iniciar la radioterapia tan pronto como la herida quirúrgica se encuentre curada por la propensión de este tumor a la repoblación.

En nuestro caso procedimos a realizar Cirugía seguida de tratamiento Radioterápico aproximadamente un mes tras la intervención.

La Radioterapia, a dosis de 45-60 Gy también se ha utilizado de forma aislada obteniendo niveles adecuados de control local lo que refuerza la descripción de este tumor como radiosensible. ${ }^{13,14}$ Creemos que en cualquier caso, la extirpación quirúrgica inicial de la lesión es obligada.

Estadio II: El manejo de la localización primaria es similar al descrito para el estadio I. En caso de que exista afectación ganglionar la tasa de supervivencia a 5 años, cae hasta el $47 \%$. No está definido si la extirpación quirúrgica de los ganglios linfáticos afectados es superior al tratamiento aislado con radioterapia. Con frecuencia esta afectación ganglionar se presenta en forma de grandes conglomerados adenopáticos que pueden resultar inoperables. Últimamente parece cada vez más evidente la necesidad de adjuntar la quimioterapia al tratamiento de aquellos pacientes de alto riesgo, bien como radiosensibilizante, bien como tratamiento coadyuvante. ${ }^{5}$

Estadio III: La existencia de enfermedad diseminada implica una reducción de la supervivencia media a menos de 9 meses. Como consecuencia, una vez diagnosticada la existencia de metástasis, el tratamiento es meramente paliativo. En la evolución de la enfermedad la aparición de metástasis oscila entre un $28-70 \%$. Las localizaciones más frecuentes incluyen: hígado, hueso, pulmón y cerebro. Las respuestas a la quimioterapia genralmente son de corta duración y en última instancia los pacientes mueren por la enfermedad. ${ }^{15}$

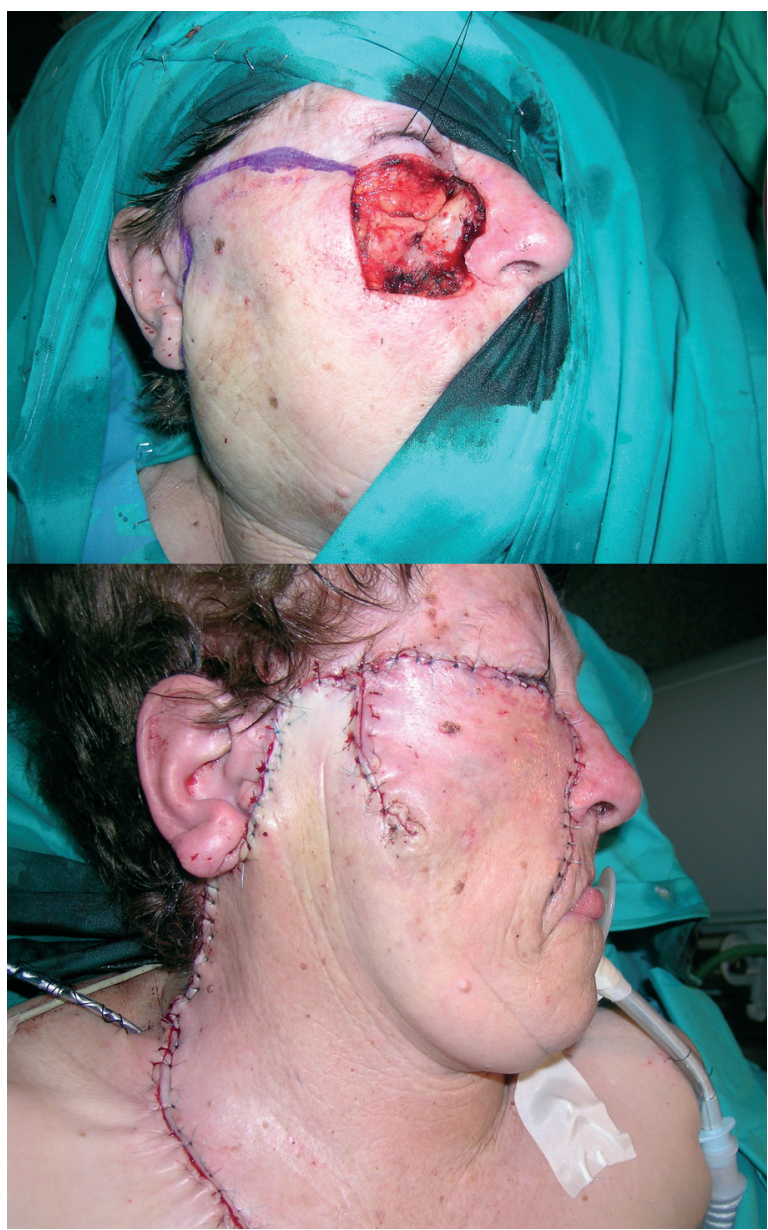

Figuras 6 y 7. Extirpación y reconstrucción del defecto con colgajo regional de rotación-avance cérvico-facial.

Figures 6 and 7. Excision and reconstruction of the defect with a regional cervico-facial rotation-advance flap.

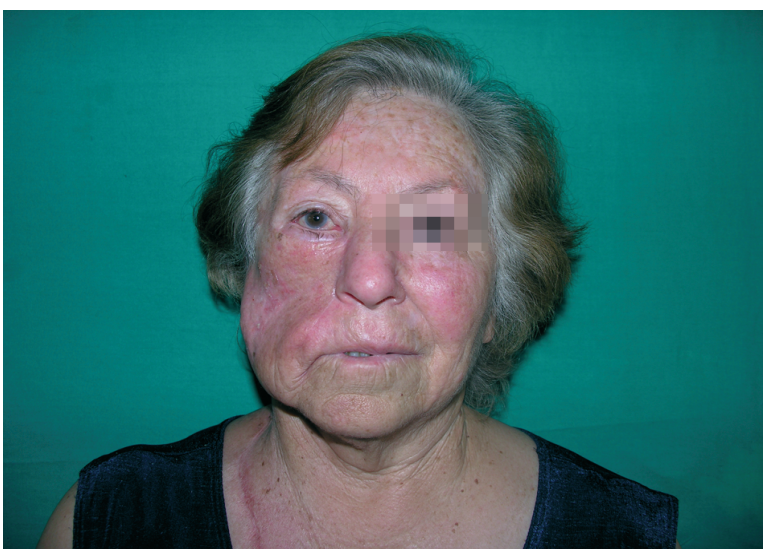

Figura 8. Imagen postoperatoria 4 meses después de finalizar la radioterapia donde se puede apreciar leve ectropion del párpado inferior derecho.

Figure 8. Postoperative image 4 months after finalizing radiation therapy. Mild eversion of the lower right eyelid can be appreciated. nodes, which improves the quality of life and reduces the risk of disease dissemination. Secondary objectives include preservation of the aesthetic appearance and function. In our patient, because of the absence of skeletal involvement, a broad excision was made with $3-\mathrm{cm}$ margins (except for the edge of the eyelid, where the margin was $2 \mathrm{~cm}$ ), including underlying periostium to rule out the presence of bone involvement.

Stage I: Surgery and irradiation are recommended. Safety margins of 2.5 to $3 \mathrm{~cm}$ are recommended. $6,8,9$ The mean 5-year survival is estimated to be $64 \%$. Many authors recommend postoperative irradiation based on retrospective studies that compare patients treated with surgery alone versus patients treated with surgery and irradiation. 10-12 Irradiation should begin as soon as the surgical wound heals due to the propensity of this tumor to recur.

Our patient underwent surgery followed by radiation therapy approximately one month after the intervention.

Radiotherapy at a dose of 4560 Gy also has been used alone, obtaining adequate levels of local control, which supports the characterization of this tumor as radiosensitive. ${ }^{13,14}$ We believe that the initial surgical excision of the lesion is obligatory in any case.

Stage II: Management of the primary site is similar to stage I. If lymph node involvement exists, the 5-year survival rate falls to $47 \%$. It is not certain whether surgical excision of the affected lymph nodes is better than radiation treatment alone. Lymph node involvement frequently appears as large lymph node clumps that may be inoperable. Lately it 


\section{Bibliografía}

1. Toker C. Trabecular carcinoma of the skin. Arch Dermatol 1972;105:107-10.

2. Tang C, Toker C. Trabecular carcinoma of the skin: an ultraestructural study. Cancer 1978;42:2311-21.

3. Goessling W. Merkel cell carcinoma. J Clin Oncol 2002;20:588-598.

4. Buell JF. Inmunosupression and Merkel cell cancer. Transplant Proc 2002;34:178091.

5. Poulsen M. High risk Merkel cell carcinoma of the skin treated with synchronous carboplatin/etoposide and radiation. / Clin Oncol 2003;21:4371-6.

6. Haag M. Merkel cell carcinoma: diagnosis and treatment. Dermatol Surg 1995; 21:669-83

7. Nguyen B. A imaging of Merkel Cell Carcinoma. Radiographics 2002;22:367-76.

8. Yiengpruksawan A.. Merkel cell carcinoma: prognosis and management. Arch Surg 1991;126:1514-9.

9. Shaw JH. Merkel Cell tumour: clinical behaviour and treatment. Br J Surg 1991;78:138-42.

10. Marks M. Radiotherapy as an adjunct in management of Merkel Cell carcinoma. Cancer 1990;65:60-4.

11. Kokoska ER. Early aggressive treatment for Merkel cell carcinoma improves outcome. Am / Surg 1997; 174:688-93.

12. Medina Franco H. Multimodality treatment of Merkel cell carcinoma: case series and review of 1024 cases. Ann Surg Oncol 2001;8:204-8.

13. Mortier L. Radiotherapy alone for primary Merkel cell carcinoma. Arch Dermatol 2003;139:1587-90.

14. Ashby M. Primary cutaneous neuroendocrine (Merkel cell or trabecular carcinoma) tumour of the skin: a radiosensitive tumour. Clin Radiol 1989;40:85-7.

15. Tai PT. Chemotherapy in neuroendocrine/Merkel cell carcinoma of the skin and review of 204 cases. J Clin Oncol 2000;18:2493-9. has become increasingly evident that chemotherapy should be added to the treatment of high risk patients, either as a radiosensitizer or as coadjuvant treatment. ${ }^{5}$

Stage III: The existence of disseminated disease reduces mean survival to less than 9 months. In consequence, if metastasis is diagnosed, treatment is merely palliative. Metastasis occurs in 28 to $70 \%$ in the course of the disease. The most frequent locations include: liver, bone, lung, and brain. The response to chemotherapy generally is of short duration and patients ultimately die from the disease. ${ }^{15}$ 